\title{
Reputation Management for Nonprofit Organizations
}

\author{
Jurgen Willems \& Carolin J. Waldner
}

\begin{abstract}
:
In this outline we give an overview of the main background of our DFG-funded project, and the main research questions we focus on. The overall objective is to bring a substantial contribution to the literature on reputation building, and in particular in the field of organizations that have a social goal.

More info on:

https://www.researchgate.net/project/Reputation-Management (look for work in progress, conference presentations, and article publications)

http://gepris.dfg.de/gepris/projekt/313624637

https://app.dimensions.ai/details/grant/grant.5325442
\end{abstract}

\section{State of the art and preliminary work}

Assessing effectiveness of nonprofit organizations has been broadly discussed in the literature due to the inherent challenges that many of these organizations face (Herman \& Renz, 2008; Lecy et al., 2012; Jun and Shiau, 2012). In short, these major challenges regard the enormous diversity of potential organizational goals, the interdependencies of goals within and across organizations, and the various stakeholder needs and preferences often combined in the context of a single organization (Willems, 2012; Helmig et al., 2013; Willems et al., 2014).

Given these challenges, the assessment of nonprofit effectiveness is often highly subjective. This subjective nature has been concretized in the literature based on two related concepts. First, nonprofit effectiveness has been argued to be a social constructionist concept (Herman \& Renz, 1999, 2004, 2008; Mitchell, 2013; Willems et al., 2014; Willems, 2015). From this perspective effectiveness is seen as an individual interpretation, based on a personal reference framework (constructionism), that might be influenced through interactions with others (the social element in social constructionism). Second, given the subjective and constructionist nature, seminal contributions have postulated the theoretical and methodological advantages of focusing on 
nonprofit reputational effectiveness, which conceptualizes the various opinions that stakeholders might have on the actual input-output performance relationship embodied by an organization (Cohen, 1993).

It is in this particular domain of these perception-based evaluations of nonprofit effectiveness that the aimed contribution of this research project will be. A major advantage of this reputational effectiveness approach is its high practical relevance given the recurrently confirmed relationship of nonprofit reputational effectiveness with concrete and actual stakeholder behaviors, such as volunteering, donating, employee work commitment and managerial decision making (Yoo and Brooks, 2005; Daellenbach et al., 2006; Sarstedt and Schloderer, 2010; Mews and Boenigk, 2012; Schloderer et al., 2014). Furthermore, given a growing acceptance in the academic and practitioner literature that a single and one-size-fits-all approach for nonprofit effectiveness measurement most likely does not exist (Liao-Troth and Dunn 1999; DiMaggio, 2001), recent structured literature reviews have pointed out that despite more than five decades of nonprofit effectiveness literature, still no convergence has happened towards broadly accepted insights or theories (Lecy et al., 2012; Jun and Shiau, 2012). Along with this deficit, the observation is made that the vast majority of studies in this domain remains qualitative, descriptive or pure theoretic (Herman \& Renz, 2008; Helmig et al., 2011). As a result, perception-based evaluations of nonprofit organizations increasingly receive more attention as a potential mediation concept between on the one hand contextual antecedents of these perceptions and on the other hand desired stakeholder behavior towards the organization.

Research gaps: Within this growing area focusing on perception-based evaluations of nonprofit organizations, two major research gaps can be identified on which this project will focus.

First, to date these social constructionist and reputational perspectives have been used to argue that nonprofit effectiveness is hard or even impossible to quantify objectively (Herman \& Renz, 1999, 2008; Liao-Troth and Dunn 1999; DiMaggio, 2001; Lecy et al., 2012). As a result, the social construction argumentation has mostly been built on for the constructionist element of it rather than for its social element. This leaves an important gap, as from a substantive point of view little is known on (1) the extent that social dynamics among individual stakeholders account for shared opinions on organizational effectiveness (Willems, 2012; Willems et al., 2012a), and (2) how shared opinions can have an impact on the decision making by stakeholders regarding the organization (e.g. by board members, donor groups, or volunteers) (Willems, 2015). However, to date nonprofit practitioners have little scientifically supported guidelines regarding strengthening their reputation among primary stakeholders (Mitchell, 2013; Willems, 2017). As a result, the process regarding how opinions among stakeholders are constructed, and how this in turn determines their actions towards the organization, need further investigation. 
Second, little is known on how stakeholder perceptions change over time, and what particular elements are at the origin of reputation building. Within this context the related concept of 'nonprofit reputational capacity' is used by the principal investigator for further investigation in this research project. This concept adds a longitudinal and cumulative perspective to the discussion where reputational capacity is the built-up perception of an organization among its stakeholders that is the output of a series of interactions between that organization and its stakeholders. Or in other words, reputational capacity is defined here as the accumulated elements of organizational reputation among a stakeholder or stakeholder group. In comparison to the broader generic concept of 'organizational reputation', which is the overall set of perceptions that exist about an organization at a certain moment of time among the total and/or unified group of perceivers (Scott \& Lane 2000; Bryce, 2007; Rindova et al. 2007; Stazyk and Goerdel, 2010), reputational capacity focusses on the concrete perceptions that can be built-up through the actions of an organization towards a particular type of stakeholders (Willems and Ingerfurth, 2018). Hence, inherent to this approach, reputational capacity can be different for different stakeholder types, and/or can be built up in a different way for different stakeholder types.

In addition to the insights already provided in earlier studies on how reputational effectiveness can influence stakeholder behavior, an important gap remains with respect to how organizations can build up their reputation over time (i.e., capacity building). In particular, it is the cumulative effect of a series of stakeholder interactions that makes the concept worth investigating. Researching how reputational capacity can be built-up and how it can buffer for negative publicity has become more relevant in the contemporary information-overloaded and media-dominated society (Helmig et al., 2011).

\section{Objectives and work programme}

The main objective of this project is to answer the question on how perceptions and reputations on nonprofit organizations are shaped (1) over time (2) through social interactions (3) with and among various groups of stakeholders. In addition, more concrete objectives include a high-quality research approach, both involving qualitative and quantitate research steps, in order to develop a thorough and well-scrutinized scientific insight in these topics. These insights should result in the concrete possibility to formulate on the one hand practical recommendations for nonprofit managers with respect to the improvement of their stakeholder management practices, and on the other hand the formulation of further concrete research avenues building on the findings of this project. From a substantive point of view, the main research aim formulated above, is cascaded-down in the following five concrete research questions (RQs): 
RQ1: What are the most relevant antecedents for reputational capacity building by nonprofit organizations, and how do these processes between antecedents and reputational effects causally work.

RQ2: How can a series of cumulatively positive interactions with stakeholders shape an organization's reputational capacity? In particular, can a positive linear, or even a positive convex relationship be assumed (meaning that there would be an additional exponential effect of multiple subsequent positive interventions), or is a concave relationship more likely to be observed (meaning that each additional stakeholder interaction can only have a decreasing marginal effect)?

RQ3: How can reputational capacity serve as a buffer for negative publicity, or for an (extreme) negative publicity event (e.g., due to a scandal in which the organization might be mentioned)? More concrete, is the impact of a negative message less strong when the organization already has built up a substantial reputational capacity?

RQ4: What organizational characteristics determine the extent that certain organizations can be more effective in reputation capacity building among particular types of stakeholders (e.g. mission valance of a particular organization for a particular type of stakeholders), and what interaction characteristics explain whether these interactions have a stronger impact with respect to capacity building?

RQ5: Which factors that vary across organizations and stakeholder groups explain the extent to which individuals share opinions on their organization's effectiveness? Or in other words, can we explain the 'strength' of the social dimension from the social constructionist perspective, depending on concrete contextual factors?

\section{Bibliography}

Beal, D.J., Cohen, R.R., Burke, M.J. \& McLendon, C.L. 2003. Cohesion and performance in groups: A meta-analytic clarification of construct relations. Journal of Applied Psychology, 88(6): 989-1004. 
Ben-Ner, A. 2002. The shifting boundaries of the mixed economy and the future of the nonprofit sector. Annals of Public and Cooperative Economics, 73(1): 5-40.

Bryce, H. J. 2007. The public's trust in nonprofit organizations: The role of relationship marketing and management. California Management Review, 49(4): 112-131.

Casey-Campbell, M., \& Martens, M. L. 2009. Sticking it all together: A critical assessment of the group cohesion-performance literature. International Journal of Management Reviews, 11(2): 223-246.

Cohen, S. A. 1993. Defining and measuring effectiveness in public management. Public Productivity \& Management Review, 17(1): 45-57.

Daellenbach, K., Davies, J., \& Ashill, N. J. 2006. Understanding sponsorship and sponsorship relationships - Multiple frames and multiple perspectives. International Journal of Nonprofit and Voluntary Sector Marketing, 11(1): 73-87.

DiMaggio, P. 2001. Measuring the impact of the nonprofit sector on society is probably impossible but possibly useful: A sociological perspective. p249-272. in Flynn P. and Hodgkinson V. Measuring the Impact of the Nonprofit Sector, Kluwer Academic/Plenum Publishers, New York.

Forbes, D. P. 1998. Measuring the unmeasurable: Empirical studies of nonprofit organizations effectiveness from 1977 to 1997. Nonprofit and Voluntary Sector Quarterly, 27(2): 183202.

Frumkin, P. 2002. On being nonprofit: A conceptual policy primer. Harvard University Press, Cambridge Massachusetts, London, England

Gaskin, K. 1999. Blurred vision: Public trust in charities. International Journal of Nonprofit and Voluntary Sector Marketing, 4(2): 163-178.

Gully, S.M., Devine, D.J. \& Whitney, D.J. 1995. A meta-analysis of cohesion and performance: Effects of level of analysis and task interdependence. Small Group Research, 26(4): 497520.

Helmig, B., Ingerfurth, S., \& Pinz, A. 2014. Success and failure of nonprofit organizations: Theoretical foundations, empirical evidence, and future research. Voluntas: International

Helmig, B., Spraul, K., \& Tremp, K. 2011. Replication studies in nonprofit research: A generalization and extension of findings regarding the media publicity of nonprofit organizations. Nonprofit and Voluntary Sector Quarterly, 41(3), 360-385.

Herman, R. D., \& Renz, D. O. 1999. Theses on nonprofit organizational effectiveness. Nonprofit and Voluntary Sector Quarterly, 28(2): 107-126.

Herman, R. D., \& Renz, D. O. 2008. Advancing nonprofit organizational effectiveness research and theory: Nine theses. Nonprofit Management \& Leadership, 18(4): 399-415. 
Herman, R. D., \& Renz, D. O. 2004. Doing things right: Effectiveness in local nonprofit organizations, a panel study. Public Administration Review, 64(6): 694-704.

Lange, D., Lee, P. M., \& Dai, Y. 2011. Organizational Reputation: A Review. Journal of Management, 37(1): 153-184.

Lecy, J. D., Schmitz, H. P., \& Swedlund, H. 2012. Non-governmental and not-for-profit organizational effectiveness: A modern synthesis. Voluntas: International Journal of Voluntary and Nonprofit Organizations, 23(2): 434-457.

Liao-Troth, M., \& Dunn, C. P. 1999. Social constructs and human Service: Managerial sensemaking of volunteer motivation. Voluntas: International Journal of Voluntary and Nonprofit Organizations, 10(4): 345-361.

Mayer, R., \& Maleham, S. 1997. The market for acute hospital services and the marketing contribution: A NHS trust experience. Journal of Nonprofit and Voluntary Sector Marketing, 2(3): 252-260.

Mechanic, D., \& Rosenthal, M. 1999. Responses of HMO Medical Directors to Trust Building in Managed Care. Milbank Quarterly, 77(3): 283-303.

Mews, M., \& Boenigk, S. 2012. Does organizational reputation influence the willingness to donate blood? International Review on Public and Nonprofit Marketing, 10(1): 49-64.

Micheli, P., \& Kennerley, M. 2005. Performance measurement frameworks in public and nonprofit sectors. Production Planning \& Control, 16(2): 125-134.

Mishina, Y., Dykes, B. J., Block, E. S., \& Pollock, T. G. 2010. Why "good" firms do bad things: The effects of high aspirations, high expectations, and prominence on the incidence of corporate illegality. Academy of Management Journal, 53(4): 701-722.

Mitchell, G. E. 2013. The construct of organizational effectiveness: Perspectives from leaders of international nonprofits in the United States. Nonprofit and Voluntary Sector Quarterly, 42(2): 324-345.

Padanyi, P., \& Gainer, B. 2003. Peer reputation in the nonprofit sector: Its role in nonprofit sector management. Corporate Reputation Review, 6(3): 252-265.

Radbournes, J. 2003. Performing on board: The link between governance and corporate reputation in nonprofit arts boards. Corporate Reputation Review, 6(3): 212-222.

Rindova, V. P., Petkova, A. P., \& Kotha, S. 2007. Standing out: How new firms in emerging markets build reputation. Strategic Organization, 5(1): 31-70.

Sarstedt, M., \& Schloderer, M. P. 2010. Developing a measurement approach for reputation of nonprofit organizations. International Journal of Nonprofit and Voluntary Sector Marketing, 15(3): 276-299. 
Schloderer, M. P., Sarstedt, M., Ringle, C. M., 2014. The relevance of reputation in the nonprofit sector: the moderating effect of socio-demographic characteristics. International Journal of Nonprofit and Voluntary Sector Marketing, 19(2): 110-126.

Scott, S. G., \& Lane, V. R. 2000. A stakeholder approach to organizational identity. Academy of Management Review, 25(1): 43-62.

Stazyk, E. C. \& Goerdely, H. T. 2010. The benefits of bureaucracy: Public managers' perceptions of political support, goal ambiguity, and organizational effectiveness. Journal of Public Administration Research and Theory, 21(4): 645-672.

Trogen, N., \& Yavas, U. 2002. Factors enhancing effectiveness of nonprofit multihospital organizations. Public Performance \& Management Review, 26(1): 44-57.

Willems, J. 2012. Nonprofit governance and effectiveness: Beyond the organizational perspective. Accountancy \& Bedrijfskunde, 32(8): 28-35.

Willems, J. 2015. Individual perceptions on the participant and societal functionality of non-formal education for youth: Explaining differences across countries based on the Human Development Index. International Journal of Educational Development. 44:11-20.

Willems, J. 2016. Building shared mental models of organizational effectiveness in leadership teams through team member exchange quality. Nonprofit and Voluntary Sector Quarterly. 45(3): 568-592.

Willems, J., Boenigk, S., \& Jegers, M. 2014. Seven trade-offs in measuring nonprofit performance and effectiveness. Voluntas: International Journal of Voluntary and Nonprofit Organizations, 25(6): 1648-1670

Willems, J., Huybrechts, G., Jegers, M., Weijters, B., Vantilborgh, T., Bidee, J., \& Pepermans, R. 2012a. Nonprofit Governance Quality: Concept and Measurement. Journal of Social Service Research. 38(4): 561-579.

Willems, J., \& Ingerfurth, S. 2018. The quality perception gap between employees and patients in hospitals. Health Care Management Review. 43(2) 157-167.

Willems, J., Waldner, C. J., Dere, Y I., Matsuo, Y., \& Högy, K., 2017. The role of formal third-party endorsements and informal self-proclaiming signals in nonprofit reputation building. Nonprofit and Voluntary Sector Quarterly. 46(5): 1092-1105.

Willems, J. \& Walk, M. 2013. Assigning volunteer tasks: The relation between task preferences and functional motives of youth volunteers. Children and Youth Services Review, 35(6): 1030-1040. 